\title{
Asian Parliamentary Debate Simulation in EFL Classroom
}

\author{
Asriadi Rasyid ${ }^{1, *}$ and Zulwahyuni Namrullah ${ }^{2}$ \\ ${ }^{1}$ Department of English Education, Sekolah Tinggi Agama Islam Al-Azhary Mamuju, Indonesia and \\ ${ }^{2}$ Department of English Education, Universitas Muhammadiyah Parepare, Indonesia \\ *asriadi.rasyid28@gmail.com
}

\begin{abstract}
Focusing on the text book and teaching speaking by asking students to memorize vocabularies in the classroom were the main reason for students getting difficulties to improve speaking ability. The main goal of the research was to perceive the impact of Asian Parliamentary Debate simulation in improving students' speaking ability. This research employed a quasi-experimental design where the sample chosen was 79 of the second-year students at SMAN 2 Parepare. The data gathered using interview test which distributed before and after the research treatment and analyzed using quantitative analysis. The result indicated that there was a significant improvement on students' speaking score. In conclusion, teaching speaking through the implementation of Asian Parliamentary debate simulation boosted students' speaking ability.
\end{abstract}

Key words: Asian Parliamentary debate, EFL Classroom, speaking ability.

\section{Introduction}

Having a good English speaking is very essential especially for the students because it becomes the bridge for them to know the world [1]. Speaking is activity in giving and asking information as if dialoguing by two or more people [2]. It also one of the important skills in language learning besides listening, writing and reading. There are many languages learners regard speaking ability [3] as the measure of knowing a language. So, they regard that speaking as the most important skill they can acquire. Furthermore, speaking is one of the most important skills to be developed and enhanced as means of effective communication [4].

Think critically assist people in solving their problems, make a decision, and achieve the goals that make their life decisively. As a consideration, the students then are able to face certain problems in order to respond to a case. In contrast, those positive goals actually depend on students' ability on how they can think at a higher-order thinking level [5]. Debate is competition of argument, ideas, opinions involving a critical thinking process and speaking skill in which there are two opposing parties face to face and each defending their ideas or opinions or argument by rational reason [6]. The debate will improve the fluency, pronunciation and vocabulary of the students. They will also be familiar with jargons and technical terms as debating covers a variety of areas and issues [7].

Nowdays, there are many styles of parliamentary debate, those are British style, Asian style, American style, and Australian style which have each own structure of debate. Asian Parliamentary style is a common form of academic debate. It has gained support in the United Kingdom, Ireland, Canada, India, Europe, Africa, Philippines and United States, and has also been adopted as the official style of the World Universities Debating Championship 
and European Universities Debating Championship [8]. Asian Parliamentary Debate is an academic debate event on Asian parliamentary system. In this research, the debate system is simulated to assist students in communicate their ideas, feeling, emotion, and thoughts in spoken language at an EFL classroom at secondary school level in one regency in south Sulawesi province of Indonesia.

\section{Theoretical Reviews}

\section{Definition Of Speaking}

Speaking is not only having amount of vocabularies and knowing the grammatical structures, but also mastering all elements of speaking above [2]. All messages we deliver will be acceptable by all communicants if we master those elements. Besides, [9] speaking is a crucial part of second language learning and teaching, it's an art of communications and one of 4 productive skills, that must mastered in learning foreign language. Good speaking skills are the act of generating words that can be understood by the listeners. It is a process to building and sharing meaning which is uses of verbal and non-verbal symbol. It is also about express mind, feeling, receiving and processing information.

\section{The Difficulties of Speaking}

There are many factors that cause difficulties in speaking, including:

- Students are worried about making mistakes fearful of criticism, or simply shy.

- Students have no motivation to express themselves, only one participant can talk at a time because of large classes and the tendency of some learners to dominate while others speak very little or not at all.

- Learners who share the same mother tongue tend to use it because it is easier and because they feel less exposed if they speak their mother tongue [10].

Furthermore, there are three major speaking difficulties namely linguistic difficulties, mother tongue use, and inhibition [10]

\section{Components of Speaking}

We could suggest that the basic components of speech are:

1. Grammatical competence is using and conceiving grammatical structures accurately and promptly relative to fluency.

2. Sociolinguistic competence consists of speech acts such as apologies and compliments.

3. Discourse competence concerns effective negotiation of ideas within a given discourse.

4. And strategic competence is when speakers have mastered language strategies, allowing them to spread their ability to communicate effectifely in their new language [6].

Moreover, in general the elements of speaking skills classifies into the 'accuracy', 'fluency' and 'comprehensibility'. The accuracy is concerned with the 'grammar, vocabulary, and pronunciation' [1][11]. If someone speaks English, the understanding of the English grammar should be paid attention in order that the utterances produced are grammatically correct, so that the listener understands those utterances. Similarly, the vocabulary is also important in speaking skills. large vocabulary should be improved in order that the words might be used appropriately. One cannot communicate effectively or express their ideas both oral and written form if they do not have sufficient vocabulary, without vocabulary nothing can be conveyed. Another element of speaking skills is 'pronunciation'. It is the way for students to produce clearer language when they speak.

\section{Definition of Debate}

Debate is an activity in which students take up positions on issue and defend their position. It has also been pointed out that debating is a formal method of interactive and representational argument aimed at persuading judges and audience [2],[12] . It is a rhetoric practice in which different strategies of logic building as well as delivery are used to pull in the target audience to a conclusion on a controversial issue. Debate is an excellent activity for language learning because it engages students in a variety of cognitive and linguistic ways [13]. In addition to providing meaningful listening, speaking and writing practice, debate is also highly effective for developing argumentation skills for persuasive speech. 


\section{Benefits of Debate}

Debate is one of technique which has many benefits for students:

1. Improve students' critical thinking. In debating, every student is proposed to analyze a problem critically.

2. Develop students' communication skill. Debaters spend many hours assembling and practicing hundreds of public speeches on topics of national importance.

3. Questioning skill developed in and struggle-often in the face of disappointment and defeat.

4. They are capable of making and defending informed choices about complex issues outside of their own area of interest because they do so on a daily basis.

5. Debate is thus not only a way to connect students with academic subjects in meaningful ways; it is also a way to re-connect students to public life if they have been overcome by feelings of alienation. Policy debate specifically teaches students to adopt multiple perspectives which describe as one of the most important problemsolving skills [14].

\section{Basics of Asian Parliamentary Debate}

In the basics of the debating, the first principle of the debate is the model of the debate. In the debate, there are the affirmative/government and negative/opposition team led by a chairperson and no interruption is allowed during the debate [15]. The speech duration order is:

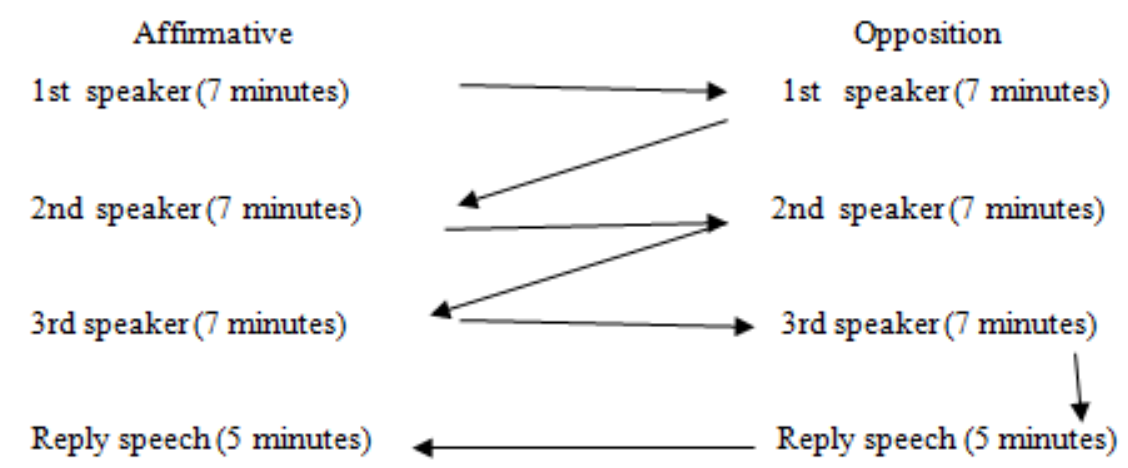

Figure 1. Speech Order in Asian Parliamentary Debate

Based on the previous explanation about speech duration, the researcher concluded that every members of debate has 7 minutes to used except reply speaker where only has 5 minutes. All the speech duration it used to explain the argument or case of every team whether they are affirmative or negative team.The implementation of Asian parliamentary debate simulation make the students' became more active in the teaching and learning process [16]. It also makes the students' tended to be communicative, following the learning well, being creative, being cooperative and so forth. In aspect of bravery to deliver the argument and also ask the question to the teacher. Thus, by implementing the simulation, the researcher had encouraged students to be accustomed to speaking up and deliver their arguments [17].

\section{Motion}

Motion is topic that will talk in inside of debate by affirmative team and opposition team. There must be a motion or topic for each debate. The motion is announced before the debate begins and after the topic or motion is given, those two teams of debaters are given 10 up to 30 minutes to prepare for their case (sets of arguments supported by evidence). Teams are assigned to positions in the debate randomly. The teams prepare during these fifteen minutes using their own knowledge and experience to create their case.

\section{Case}

After the topic is choosen, the debaters should gather some ideas that related to the topic. The debaters should determine the thesis argument, and set of arguments supported by evidences with the elements: 
- Definition (clarification of motion)

A definition clarifies the motion and gives the clear boundaries to the motion, limiting what the debate will be about into a focus area of discussion. Definition should cover the whole motion and present the debatable and reasonable to the link of the motion in order to avoid the confusing among the two teams. A definition is simply to clarify the motion [18]. The Government/Affirmative team must give a definition that gives room for the Opposition/Negative team to oppose it.

- Theme line (core argument or basic idea)

Theme line consists of logic arguments that will be presented as the idea to strengthen the team. The team line in the team must heavily imbue each speech of every team members. It is the main idea that link together the first, second and third speakers, ensuring consistency among all speeches.

- Team split (distribution of arguments to each speaker)

Argument should have A-R-E-L, where A as Assertion; statement of the argument, R as Reasoning; explanation of the arguments, E as Evidence; facts, statistics, L as Link back. The distribution is given to the first and the second speaker. The second speaker usually gets more split than the first speaker because the first speaker has motion, the theme line and the team split.

- Rebuttal

Rebuttal is the way on how the opposing team shows the irrelevant topic with the proof that is given by the speaker. Rebuttal is usually done by the opposing team when they determinate the illogical idea from the opponent.

- Point of Information

Points of information (or POIs) are a feature of parliamentary debate, where allowing an opposing team member to voice out the quesition and offer a brief point during the current speech. They often may not be offered in the first or last minute of any speech or during reply speeches. Points of information may never be offered to a member of the same team.

\section{The Assessment of Asian Parliamantary Debats}

In adjudicating the debate, the adjudicator uses three criteria. They are matter (content 40\%), manner (delivery 40\%), method (structure $20 \%$ ). The three criteria of the debate assessment are explained:

\section{- Matter}

Matter is the content of the speech. It can be contrasted with the presentation style of the speech (manner) and the structure of the speech (method). Matter includes arguments, evidence presented to support those arguments, examples and analysis. Matter includes substantive matter, rebuttal and points of information [19].

- Manner

There are several elements in adjudicating a manner in debate. They are defined:

- Body language

The body language of a speaker is a very important element of their speaking style. As the expression indicates, body language is a language of its own [1]. It can have a significant impact on an audience and can create powerful impressions such as confidence, trust and credibility.especially for adjudicator.

- Vocal style

The second element of manner is the vocal style of the speaker. All speakers must have their message heard and understood. Vocal style is central to this goal. Some of the elements of vocal style are volume and pace, tone, clarity and the use of language [19].

\section{- Method}

Method is the response to the dynamics of the debate, and the observance of the rules of debate. It is about how the structure of the speaker in delivery their idea in debate. Furthermore, Each speaker is required to speak based on the rules of the debate. They must deliver their cases based on their duties. When they are accustomed to implementing this, the students are eventually skillful at structuring good arguments [17].

\section{Methodology}

This research employed classroom experimental research by using control group and experimental group. The sample of this research was the second-year students of SMA Negeri 2 Parepare. The class of XI.IPA.2 consists of 39 students that treated as experimental group and class XI.IPA.3 consists of 40 students as control group. The instruments used were interview test that consist of several topics. The students will choose one topic to be explained. The data collected after giving pre-test and post-test through quantitative analysis. The data analyzed by employing the scoring classification of Heaton. 


\section{Findings and Discussion}

In obtaining the rate score of students' speaking ability, the researcher gave interview test for the students after the treatment. Based on the data result, it shows that the students' post-test score students $18(46.1 \%)$ were in fair classification, $21(53.8 \%)$ students were in good classification and none of them got very good and poor classification. In control class, $36(90 \%)$ students were in fair classification, $2(5 \%)$ students were in good classification, $2(5 \%)$ students in poor classification and none of them got very good classification. This indicates that after giving treatment, the rate precentage of the students' speaking ability in experimental and control had improved. The rate of frequency and percentage score in experimental group and control group can indicated in the following table

Table 1. The Frequency and Precentage Score of The Students in Experimental and Control Class

\begin{tabular}{|c|c|c|c|c|c|c|c|c|c|c|}
\hline \multirow[b]{3}{*}{ Interval } & \multirow[b]{3}{*}{$\begin{array}{l}\text { Predicate of Knowledge } \\
\text { and Skill Competence }\end{array}$} & \multirow[b]{3}{*}{$\begin{array}{l}\text { Classification of } \\
\text { Attitude }\end{array}$} & \multicolumn{4}{|c|}{ Experimental Group } & \multicolumn{4}{|c|}{ Control Group } \\
\hline & & & \multicolumn{2}{|c|}{ Prestest } & \multicolumn{2}{|c|}{ Posttest } & \multicolumn{2}{|c|}{ Prestest } & \multicolumn{2}{|c|}{ Posttest } \\
\hline & & & $\mathrm{F}$ & $\%$ & $\mathrm{~F}$ & $\%$ & $\mathrm{~F}$ & $\%$ & $\mathrm{~F}$ & $\%$ \\
\hline $94-100$ & A & Very Good & 0 & 0 & 0 & 0 & 0 & 0 & 0 & 0 \\
\hline $86-93$ & A- & & & & & & & & & \\
\hline $78-85$ & $B+$ & & 0 & 0 & 21 & 53.8 & 0 & 0 & 2 & 5 \\
\hline $70-75$ & B & Good & & & & & & & & \\
\hline $62-69$ & B- & & & & & & & & & \\
\hline $56-61$ & $C+$ & & 13 & 33.3 & 18 & 46.1 & 0 & 0 & 36 & 90 \\
\hline $\begin{array}{l}47-55 \\
38-46\end{array}$ & $\begin{array}{l}\mathrm{C} \\
\mathrm{C}-\end{array}$ & Fair & & & & & & & & \\
\hline $29-37$ & $D+$ & Poor & 26 & 66.6 & 0 & 0 & 40 & 0 & 2 & 5 \\
\hline \multirow[t]{2}{*}{$0-28$} & D & & & & & & & & & \\
\hline & Total & & 39 & 100 & 39 & 100 & 40 & 100 & 40 & 100 \\
\hline
\end{tabular}

In order to find out the mean score of the students' speaking ability both in the experimental and control group, the data then analyzed by using SPSS version 21. Based on result of the students' mean score and standard deviation in pre-test and post-test were presented in the following table.

Table 2. Gender research patterns in Indonesian folktales

\begin{tabular}{lcccccc}
\hline & & \multicolumn{2}{c}{ Pretest } & & \multicolumn{2}{c}{ Posttest } \\
\cline { 3 - 4 } \cline { 6 - 7 } Group & $N$ & Mean & Std.Deviation & & Mean & Std.Deviation \\
\hline Experimental & 39 & 34.43 & 7.64 & & 63.10 & 6.43 \\
Control & 40 & 23.46 & 5.83 & & 46.79 & 8.04
\end{tabular}

Based on the data above, the mean score of the experimental group in the pretest and posttest was higher than in control group, namely $34.43 \geq 23.46$ in the pretest, and $63.10 \geq 46.79$ in the posttest. Furthermore, the data collected from the students' mean score of the pretest and posttest can be analyzed to find out their standard deviation both in the control and experimental group.

After finding out the mean score and their standard deviation of both groups, the data then analyzed by using independent test at the level of significance with $\alpha=0.05$. independent test at the level of significance with $\alpha=0.05$. The result shows that the probability value (0.000) is lower than the significance value $\alpha=(0.05)$. The analysis shown that the alternative hypothesis (H1) is accepted. It means that the second-year students' speaking ability at SMA Negeri 2 Parepare of academic year 2016/2017 for experimental class and control class was significantly different.

\section{Conclusion}

Based on the findings and discussion of the study, it can be concluded that the Implementation of Asian Parliamentary Debate Simulation was able to improve the students' speaking ability in EFL Classroom. It is proved by the improvement of the students' mean score from 34.43 up to 63.10. on the other hand, by the significant difference of independent test result between experimental and control class. It is also supported by the significant of gain score result for both classes. 


\section{References}

[1] A. A. Indramawan, "Improving the Students ' English Speaking Competence through Storytelling ( Study in Pangeran Diponegoro Islamic College ( STAI ) of Nganjuk , East Java , Indonesia )," Int. J. Lang. Lit., vol. 1, no. 2, pp. 18-24, 2013.

[2] F. Arung, U. Sembilanbelas, N. Kolaka, D. S. View, and F. Arung, "Improving the Students ' Speaking Skill through Debate Technique," no. April, 2016.

[3] S. Nazara, "Students ' Perception on EFL Speaking Skill Development," vol. 1, no. 1, pp. 28-43, 2011.

[4] L. Leong and S. M. Ahmadi, "An Analysis of Factors Influencing Learners ' English Speaking Skill," pp. 34-41, 2000.

[5] F. M. Nanlohy, "Case Study: The Use of British Parliamentary Debate System and Critical Thinking," Matai Int. J. Lang. Educ., vol. 1, no. 1, pp. 37-49, 2020, [Online]. Available: https://ojs3.unpatti.ac.id/index.php/matail/ article/view/2771.

[6] S. Somjai and A. Jansem, "THE USE OF DEBATE TECHNIQUE TO DEVELOP SPEAKING ABILITY OF GRADE TEN STUDENTS AT BODINDECHA ( SING SINGHASENI ) SCHOOL," vol. 13, no. 13, pp. 27-31, 2015.

[7] U. Fauzan, "Enhancing Speaking Ability of EFL Students through Debate and Peer Assessment," EFL J., vol. 1, no. 1, p. 49, 2016, doi: 10.21462/eflj.v1i1.8.

[8] H. Yulia, "The Implementation of British Parliamentary Debate Style Training to Improve Second Semes ter Student 's Speaking Ability at English Education Study Program of Baturaja University," vol. 1, no. 1, pp. 1-7, 2017.

[9] M. Bahadorfar and R. Omidvar, "Technology in teaching speaking skill," Acme Int. J. Multidiscip. Res., vol. 2, no. 4, pp. 9-13, 2014, [Online]. Available: http://www. aijmr.net.

[10] S. Al Hosni, "Speaking Difficulties Encountered by Young EFL Learners," Ijsell, vol. 2, no. 6, pp. 22-30, 2014.

[11] R. Richa, "English language teaching department faculty of tarbiyah walisongo state institute for islamic studies 2010," Improv. Students' Speak. Ski. Through Debate Tech., pp. 1-47, 2010, [Online]. Available: http: //library.walisongo.ac.id.

[12] A. Alasmari and S. S. Ahmed, "Using debate in EFL classes," tEnglish Lang. Teach., vol. 6, no. 1, pp. 147-152, 2013, doi: 10.5539/elt.v6n1p147.

[13] B. O. Gudu, "Teaching Speaking Skills in English Language Using Classroom Activities in Secondary School Level in Eldoret Municipality, Kenya," J. Educ. Pract., vol. 6, no. 35, pp. 55-63, 2015.

[14] J. Bellon, "a Research-Based Justification for Debate Across the Curriculum, Argumentation and advocacy, vol. 36, no. 3, pp. 161-175, 2000.

[15] Birshan, Michael. "Debating Handbook". Monash: Monash University Press. 2010. Retrieved from http://www . monashdebaters. com/downloads/MAD\%20Training\%20Handbook\%202010.pdf

[16] Sanjaya., et. al. "The Implementation of Asian-Parliamentary Debate in Teaching Speaking at Senior High School”. Lampung: Universitas Lampung. 2014.

[17] U. A. D. Tefl and I. Conference, "UAD TEFL International Conference 2014," 2014.

[18] Pramanasari, et.al. "Monash Association of Debaters Member Training Handbook," Time, pp. 1-79, 2010.

[19] D'cruz, Ray. "The Australia-Asia Debating Guide”. North Melbourne: The Australian Debating Federation. Available: https://debate.uvm. edu/dcpdf/D'Cruz_Full\%20Guide\%20to\%20Australs\%20Debating.pdf. 